\begin{tabular}{|c|c|c|c|c|c|c|}
\hline \multirow{4}{*}{ Impact Factor: } & ISRA (India) & $=3.117$ & SIS (USA) & $=0.912$ & ICV (Poland) & $=6.630$ \\
\hline & ISI (Dubai, UAE & $=0.829$ & РИНЦ (Russia & $=\mathbf{0 . 1 5 6}$ & PIF (India) & $=1.940$ \\
\hline & GIF (Australia) & $=0.564$ & ESJI (KZ) & $=8.716$ & IBI (India) & $=4.260$ \\
\hline & JIF & $=1.500$ & SJIF (Morocco & $=\mathbf{5 . 6 6 7}$ & OAJI (USA) & $=0.350$ \\
\hline
\end{tabular}

\section{SOI: 1.1/TAS DOI: 10.15863/TAS International Scientific Journal Theoretical \& Applied Science}

\author{
p-ISSN: 2308-4944 (print) e-ISSN: 2409-0085 (online) \\ Year: $2019 \quad$ Issue: $04 \quad$ Volume: 72 \\ Published: $30.04 .2019 \quad$ http://T-Science.org
}

QR - Issue

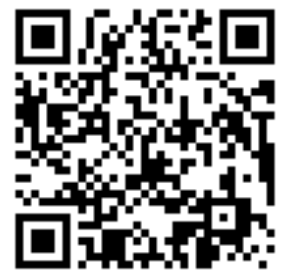

QR - Article

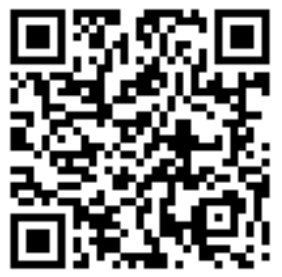

Madina Baxreddinovna Ganixanova senior teacher

Tashkent State Technical University named after Islam Karimov

UDC 81-139

\title{
USING MEDIA TECHNOLOGY IN THE TEACHING FOREIGN LANGUAGE IN TECHNICAL HIGHER EDUCATION
}

\author{
Abstract: The article highlights on the investigation of the main peculiarities of using modern communication \\ media, namely multimedia, while teaching English in technical university. \\ Key words: information technology, multimedia, multimedia tutorial, teaching foreign languages. \\ Language: English \\ Citation: Ganixanova, M. B. (2019). Using media technology in the teaching foreign language in technical \\ higher education. ISJ Theoretical \& Applied Science, 04 (72), 455-458. \\ Soi: http://s-o-i.org/1.1/TAS-04-72-56 Doi: crossef https://dx.doi.org/10.15863/TAS.2019.04.72.56
}

\section{Introduction}

The leading country in the world community will undoubtedly be the one that creates the most effective educational system capable of developing scientific intellectual, spiritual, technological potential and educating young people in the spirit of boundless devotion and patriotism to their homeland, its ideals and traditions, love for humanity, the environment.

At present, the state educational system is in anticipation of transition to a new stage of development and requires a radical restructuring of the existing teaching methodology. It is necessary to introduce new methods of teaching and verified information transmission technology using educational films for any complex information transmission unit becomes easily digestible and available to the public. To this end, it is necessary to widely use in the field of education and culture new technologies that are successfully used in the advertising and television industry, in the creation of commercial films.

\section{Materials and Methods}

Multimedia are interactive (interactive) systems that provide simultaneous work with sound, animated computer graphics, video frames, static images and texts. This term refers to the simultaneous impact on the user through several information channels. In this case, the user is usually assigned an active role. In other words, multimedia is a collection of technologies that allow a computer to enter, process, store, transmit, and display (output) data types such as text, graphics, animation, digitized still images, video, sound, and speech. The word "multimedia" appeared in connection with computer technology. It was first used by English singer and performer Bob Goldstein in 1966, when he organized his newfangled show. Later this term meant any entertainment product with various sound and video effects, but only in the 1990 - ies it was finally the definition of this word: "multimedia (multimedia) is a modern computerbased information technology that allows to combine in a computer system text, sound, video, illustration and animation (animation) - multimedia includes combination of text, audio, still images, animation, video or forms of interaction content."

The use of new communication media in the educational process provides an increase in the informative capacity of the content of the training session, because contributes to the implementation of educational, educational and developmental functions of training; reduces time, allows you to absorb more knowledge; focuses on the assimilation of the most complex topics and concepts; allows you to improve the selection of tasks and exercises, making them more visual and interesting); forms skills and abilities due to individualization of training and development of skills of independent work

The use of media in the vocational training of students is associated with the following significant functions:

- modeling of the studied processes;

- showing the considered events, phenomena and processes in the dynamics of their retrospective and perspective interpretation; 


\begin{tabular}{|c|c|c|c|c|c|c|}
\hline \multirow{4}{*}{ Impact Factor: } & ISRA (India) & $=3.117$ & SIS (USA) & $=0.912$ & ICV (Poland) & $=6.630$ \\
\hline & ISI (Dubai, UAE & $=0.829$ & РИНЦ (Russia & $=0.156$ & PIF (India) & $=1.940$ \\
\hline & GIF (Australia) & $=0.564$ & ESJI (KZ) & $=8.716$ & IBI (India) & $=4.260$ \\
\hline & JIF & $=1.500$ & SJIF (Morocco & $=\mathbf{5 . 6 6 7}$ & OAJI (USA) & $=0.350$ \\
\hline
\end{tabular}

- computer visualization and reflection on the big screen of inaccessible to the direct perception of processes and phenomena;

- interactive control of the considered processes modeled on the screen (virtual participation of students in the analyzed process or phenomenon);

- individualization and differentiation of the learning process (regulation of the information richness of the classes conducted, taking into account the individual characteristics of students);

- implementation of current and final control over the cognitive activity of students with the establishment of feedback;

- providing free access to global and local information networks;

- the emotionality and expressiveness of the transmitted educational information;

- demonstration of the studied processes and phenomena of a sufficiently large educational audience;

- increased learning motivation.

Modern information technologies require higher educational institutions to introduce new approaches to learning, ensuring the development of communicative, creative and professional knowledge, needs for self-education. The introduction of information technology in the educational process of the university moves to a new stage - the introduction of new multimedia educational materials

Multimedia tutorials have many advantages over traditional teaching methods. They allow you to train different types of speech activity and combine them in different combinations, help to realize language phenomena, form linguistic abilities, create communicative situations, automate language and speech actions, and also provide the ability to account for the leading representative system, the implementation of an individual approach and the intensification of student independent work.

It should be noted that with the help of modern multimedia technologies it is possible to expand the range of presentation of educational material in comparison with traditional. For example, the presence of a network computer terminal allows you to: search for reference material in the local and global network; find relevant information from various fields of knowledge; organize interactive communication with native speakers; visualize the training material in various ways; create your own presentations in a foreign language using various means.

It should also be noted that the use of the latest technologies provides both the teacher and the student a number of advantages:

1) the possibility of combining imaginative and logical ways of mastering information;

2) activation of the educational process by increasing visibility;
3) interactive interaction, allowing, within certain limits, to control the presentation of information, individually change the settings;

4) the ability to create a virtual environment as close to natural conditions;

5) visualization of complex schemes, internal processes and phenomena using three-dimensional computer animation; attraction of video fragments and extensive illustrative material; it turns learning into a fascinating process and helps to increase the motivation of students;

6) flexibility and integration of different types of multimedia educational information;

7) becoming an active participant in the educational process, which uses multimedia technologies (network technologies, electronic, etc.), the student from the object becomes the subject of communicative communication with the teacher, which develops independence and creativity in his educational activities.

Digital animation programs allow you to create visual processes that can be effectively used in creating educational films. The use of digital technologies (sound-image) is necessary not only to improve the level of education of students and youth, but also to involve the bulk in the educational process, which is the main condition for the development of society's potential. The importance and importance of this problem multiplied and continuously grow with the transition from individual (one teacher to one student) to mass (group) learning, when the audience is a whole class or classroom.

In order to solve this problem in the modern conditions of science and technology development, information and telecommunication technology, taking into account the accelerated and continuous growth of the demand for knowledge (education), it is necessary to introduce the latest methods of medical technology in the teaching process in educational institutions of all systems.

At present, the educational institutions in the educational process (primarily in the higher and secondary special educational institutions) to enhance learning, better and better digestibility of the material used different equipment and technical training (TCO), such as projectors, slide projectors, slaydoscopy, television systems, Computers, moderators, lingaphones and many types of active teaching methods: business games, organizational and activity games, distance learning, traditional lectures, seminars, workshops Collegiums, debates, round tables, conferences, etc.

The essence of the content of medical technology and its application in the teaching and learning process lies in the fact that with this method, subject to its normal organization and skillful application, all students-listeners, regardless of their ability and education, have a personal interest in the subject and the problem in question, and Also the 


\begin{tabular}{|c|c|c|c|c|c|c|}
\hline \multirow{4}{*}{ Impact Factor: } & ISRA (India) & $=3.117$ & SIS (USA) & $=0.912$ & ICV (Poland) & $=6.630$ \\
\hline & ISI (Dubai, UAE & $=0.829$ & РИНЦ (Russia) & $=0.156$ & PIF (India) & $=1.940$ \\
\hline & GIF (Australia) & $=0.564$ & ESJI (KZ) & $=8.716$ & IBI (India) & $=4.260$ \\
\hline & JIF & $=1.500$ & SJIF (Morocco & $=5.667$ & OAJI (USA) & $=0.350$ \\
\hline
\end{tabular}

desire to actively participate in the process of discussing the issue. Almost there will be no possibility to distract.

Currently, there is a diagram "pupil - classroom - the teacher" in the educational process, in which, first, the teacher-media information plays an authoritarian role, and the result of learning assessment, and secondly, the knowledge is distributed in disciplines that do not intersect. The school methodology does not provide for free analysis in the learning process, it is a deviation from discipline. Thirdly, increasing the communicative capacity of the audience is not seen as a factor that reveals the individual abilities inherent in each individual student of the school, which has an "impersonal character."

In contrast to this, when introduced into the scheme of "teacher - reflecting" educational films with a specialized procedure accompaniment barrier created by the circuit "pupil - audience - teacher" markedly fade and between teacher and pupil is set free, democratic, vowel working environment, forcing Liberate the listener, freely reflect and openly express their opinions (even if this is not entirely true).

Teaching Tel meditating

The position of the teacher is democratic. Assimilation of the object is achieved by increasing the natural interest in learning. In addition to films on the curriculum, intellectual films that develop thinking and judgment are used. The result of the training is understanding and mastering the discipline.

Consistent universal content

The disciplines in which the training takes place intersect each other. Free analysis is allowed. The focus of the educational process is aimed at understanding the internal relationships of the subjects studied.

Social character

One of the main tasks of the teacher is the purposeful alignment of the communicative capacity of the audience and each pupil of the school to disclose the individual abilities inherent in it.

The proposed concept of the methodology of secondary education only complements, without eliminating the introduction of the norm of teaching. This addition is focused on improving the quality of information transfer and on increasing the role of education and upbringing of youth in a purposeful stage-by-stage reform of society. Digital technology allows:

To model audio and visual processes of any complexity, simplifying them for perception and memorization.

Specialized films created by the curriculum will significantly increase the interest in learning. The time of transfer and assimilation of information will be markedly reduced, which will optimize the educational process.
Educational film-a way of structuring the information using the plot, the method by which consistently sets out a large block of information of the curriculum. The barriers that arise between the student and the teacher are disappearing, since the goal of communication between the teacher and the students is not the presentation of information, but the discussion and consolidation. The film defines the content of communication. In this case, the teacher becomes a participant in the discussion. Thus, the existing educational practice, which is a role communication, expands, and in the proposed methodology the teacher and pupils are asked questions (interpersonal communication), where the dialogue participants (teacher-student) are individuals who express themselves in the course of communication.

In projects for the restructuring of secondary education, little mention is made of the training of teachers (higher education), which is the starting point in the development of secondary education. This relationship requires informers of the educational system to create new institutions aimed at the development of modern intellectual society. It is necessary to start with the most effective solution, namely with the introduction of educational films and the methods of their accompaniment in the learning process.

The project provides for the development of a methodology for accompanying educational films in the uniting direction: science, psychology, sociology, art and new technology.

\section{Conclusion}

As a result, gradual restructuring of the state of the education system involves consideration of the effect of education in the need for a global vision of the future of the country.

In addition, it is important to note the shift in the emphasis of learning from group to individual, which is characterized by a differentiated personalityoriented approach that allows to remove the psychological difficulties of learning. Thus, in the educational process there is a redistribution of functions of the student and the teacher. Thus, in the traditional approach, the teacher plays a leading role, which is to inform and control, the student passively assimilates the knowledge taught, followed by their reproduction. In the process of reorientation to interactive learning both participants of the educational process are almost equal. The teacher becomes an assistant consultant, and the student has the opportunity to take responsibility for the acquisition of knowledge and, therefore, takes an active cognitive position.

The inclusion of modern information technologies in the educational process undoubtedly contributes to the quality of education. Nevertheless, it should be recognized that the level of 


\begin{tabular}{|c|c|c|c|c|c|c|}
\hline \multirow{4}{*}{ Impact Factor: } & ISRA (India) & $=3.117$ & SIS (USA) & $=0.912$ & ICV (Poland) & $=6.630$ \\
\hline & ISI (Dubai, UAE & $=0.829$ & РИНЦ (Russia & $=0.156$ & PIF (India) & $=1.940$ \\
\hline & GIF (Australia) & $=0.564$ & ESJI (KZ) & $=8.716$ & IBI (India) & $=4.260$ \\
\hline & JIF & $=1.500$ & SJIF (Morocco & $=\mathbf{5 . 6 6 7}$ & OAJI (USA) & $=0.350$ \\
\hline
\end{tabular}

informatization of educational and scientific activities of universities is still quite low. Currently, the introduction of information technology and the Internet in the educational process of secondary schools and universities is limited and does not always adequately correspond to the plans and programs of work. Undoubtedly, it is the University that should play a major role in the development of information educational technologies. The most important tasks are: the development of various forms of distance learning and the creation of electronic libraries and educational databases, Modernization and development of the existing network infrastructure, increasing the capacity of the channels used.

\section{References:}

1. Sumina, G. A., \& Ushakova, N. Y. (2007). the use of multimedia technologies in the educational process of the University. scientific journal "achievements of modern natural science", №5.

2. Khlyzova, N. Y. (2008). Multimedia and their capabilities in the organization of the process of teaching students English [Text]. pedagogical theory, experiment, practice. Edited by T. A. Stefanovskaya (Eds.). (pp.275-286). Irkutsk: publishing house Irkut. In-tpowis. qualif. works. 'education.

3. Farkhodzhonova, N. F. (2016). Problemy primeneniya innovatsionnykh tekhnologiy $v$ obrazovatel"nom protsesse na mezhdunarodnom urovne. Innovatsionnye tendentsii, sotsial'noekonomicheskie i pravovye problemy vzaimodeystviya v mezhdunarodnom prostranstve. pp. 58-61.

4. (2006). The use of multimedia in educational and professional activities: textbook for students majoring in "Social pedagogy" / Comp. V. V. Mantulenko (Eds.). (p.36). Samara: publishing House "universe group".
5. McDonough, J., \& Shaw, C. (2003). Materials and Methods in ELT: A teacher's guide. 2nd edition. (p.280). Malden: Blackwell.

6. Richards, J. C., \& Rodgers, T. S. (2001). Approaches and Methods in Language Teaching. (p.171). Cambridge: Cambridge University Press.

7. Moiseev, A. P. (2008). Complex approach to the use of technical means of training in the classroom for the practice of oral and written speech. Retrieved May 21, 2008, from http://pn.pglu.ru/index.php?module=subjects\&f $\underline{\text { unc }=\text { printpage } \& \text { pageid }=2151 \& \text { scope }=\text { page }}$

8. Popova, G. S. (2008). The role of the computer in teaching English. Retrieved May 21, 2008, from http://ito.su/2003/II/2/II-2-1785.html

9. Protopopova, V. V. (2010). Methodological aspects of integration of higher professional education and modern information technologies. Bulletin of Samara Municipal Institute of Management, №1(12).

10. Thacker, C., \& Pelteret, C. (2007). English in Mind. Teacher's Book 1. (p.130). Cambridge: Cambridge University Press. 